\title{
Effect of tillage practices on soil moisture in vertisol
}

\author{
SACHIN S. BHAGADE, KAPIL K. SAMAR AND AMOL D. SHURPATNE
}

\begin{abstract}
Effect of tillage practices on soil moisture conservation practices in vertisol was carried out during Kharif-2012 at All India Co-ordinated Research Project (AICRP) for dryland agriculture farm, Marathwada Agricultural University, Parbhani, to know the effect of tillage practices on soil moisture content in the soil regime. Four treatments from $10 \mathrm{~cm}$ to $40 \mathrm{~cm}$; were adopted. It was found that ploughing across the slope up to $30 \mathrm{~cm}$ depth is beneficial.
\end{abstract}

KEY WORDS : Tillage practices, Soil moisture, Vertisol

How to cite this Article : Bhagade, Sachin S., Samar, Kapil K. and Shurpatne, Amol D. (2014). Effect of tillage practices on soil moisture in vertisol. Engg. \& Tech. in India, 5 (1\&2) : 49-53. 